\title{
Õpilase vaimse võimekuse ja klassi õpikeskkonna seos akadeemilise edukusega kakskeelsetel ja nendega koos õppivatel eestikeelsetel
}

\author{
Kristina Seepter ${ }^{\mathrm{a} 1}$ \\ a Tallinna Ülikooli psühholoogia instituut
}

\begin{abstract}
Annotatsioon
Uurimuse eesmärk oli analüüsida, kuidas arenevad eesti koolis koos õppivad eesti- ja kakskeelsed lapsed. Selleks analüüsiti, kas õpilase vaimne baasvõimekus oli realiseerunud akadeemilises plaanis nii matemaatikas kui ka eesti keele mõistmises. Lisaks kirjeldati, millised klassi õpikeskkonnad toetavad õpilaste arengut ja millised laste akadeemilised tulemused olid vastavuses nende võimekusega ning millistes õpikeskkondades oli õpilastel probleeme ja nende vaimne potentsiaal ei realiseerunud.

Analüüsiti 25 klassikomplekti, kus õppisid koos nii eesti- kui ka kakskeelsed lapsed. Arvesse läks õpilase vaimse võimekuse tase 3. klassis ja tema edaspidised tulemused 5. klassi matemaatikas ja eesti keele mõistmises. Klassi õpikeskkonda kirjeldasid klassikaaslaste keskmine IQ tase ja selle varieeruvus klassis ning õpetaja üldine toimetulek selle klassikomplekti õpetamisel. Andmeanalüüsimeetoditest kasutati nii rühmatasandi meetodeid (nt dispersioon- ja hulgiregressioonanalüüsi) kui ka indiviiditasandi meetodeid (nt konfiguratsioonilist sagedusanalüüsi).

Tulemused osutasid, et aineõppele ülemineku perioodi alguseks (5. klass) olid matemaatikateadmised kakskeelsetel õpilastel jõudnud sarnasele tasemele kui samas õpikeskkonnas õppivatel eestikeelsetel lastel, ent eesti keele mõistmises püsis kakskeelsete rühm kõigil kolmel aastal (3.-5. klass) oluliselt kehvemal tasemel võrreldes eestikeelsetega. Oluline on märkida, et väiksem akadeemiline edukus ei iseloomustanud ühtmoodi kõiki muukeelseid õpilasi. Võimekusele mittevastav madalam akadeemiline tase oli iseloomulik just keskpärase võimekusega kakskeelsetele lastele. Need õpilased moodustavad kakskeelsete hulgas riskirühma, kes tuleks õpetajatel ära tunda, et nende arengut paremini toetada. Uurimistulemustest ilmnes, et keskpäraste võimetega kakskeelsetel lastel oli
\end{abstract}

1 Psühholoogia instituut, Tallinna Ülikool, Narva mnt 29, 10120 Tallinn; kristina.seepter@ut.ee 
probleeme klassi õppekeskkonnas, mis oli võimete poolest ühtlane, kuid keskmisest madalama IQ tasemega. Lisaks näitasid andmed, et vaimse võimekuse mõttes heterogeensetes klassikomplektides õppis andekaid lapsi, nii eesti- kui ka kakskeelseid, kelle vaimne potentsiaal akadeemilises plaanis ei realiseerunud.

Erinevused õpilaste arengumustrites eri tüüpi klassi õpikeskkondades võivad olla tingitud õpetaja toimetuleku erinevustest. Näiteks ei suuda heterogeenses klassikeskkonnas suur hulk õpetajaid (ja ka koolikorraldusi) piisavalt toetada kõigi klassis koos õppivate lasterühmade arengut. Tavaliselt kannatavad kõige rohkem keskpärase ja kõrge võimekuse tasemega lapsed, kelle akadeemilised tulemused jäävad alla nende vaimsele potentsiaalile.

Võtmesõnad: eksploratiivne longituud- ehk pikiuurimus, kakskeelsed, õpilase IQ tase, kaasõpilase keskmine IQ tase ja varieeruvus, õpetaja üldine toimetulek, akadeemiline edukus

\section{Teoreetiline taust}

\section{Akadeemiline edukus üks- ja kakskeelsetel}

Akadeemilise edukuse võrdlusuuringud üks- ja kakskeelsetel on näidanud, et kakskeelsete soorituse tase on madalam kui ükskeelsetel (Bialystok, 2009; Kempert, Saalbach, \& Hardy, 2011). Näiteks PISA (Program for International Student Assessment) akadeemilise edukuse analüüsides Saksamaal on korduvalt kinnitust leidnud fakt, et kakskeelsed saavad matemaatikas, lugemises ja loodusteadustes oluliselt halvemaid tulemusi kui emakeeles õppivad õpilased. Ka Eestis on viimase aja uuringutulemused kinnitanud seda üldist tendentsi nii eesti keele grammatika tundmises (Uibu \& Tropp, 2012) kui ka matemaatikas (Kikas, 2012; Tago \& Ots, 2010). Analüüsitud on ka akadeemiliste teadmiste stabiilsust ja muutust ühe aasta vältel - 3.-4. klassini. Uibu ja Tropp (2012) näitasid, et eesti keele grammatika ülesannete puhul said ükskeelsed kakskeelsetega võrreldes paremaid tulemusi mõlemal aastal. Kakskeelsed kuulusid pigem sellisesse rühma, kus grammatikas oli stabiilselt madal tase, või ka rühma, kus tulemused olid 3. klassiga võrreldes läinud 4. klassis kehvemaks. Üksja kakskeelsete matemaatikaoskuste analüüsis leidis Kikas (2012), et tulemused olenevad matemaatika osaoskusest. Kui rutiinsete ja uudsete probleemide lahendamisel oli eestikeelne rühm üldiselt parem kui kakskeelsete oma, siis lihtsa arvutusoskuse puhul rühmadevahelisi erinevusi ei esinenud. Lisaks analüüsis Kikas (2012) laste matemaatikaarengut ja leidis, et eestija kakskeelsete arengumustrid on erinevad ja areng sõltub õpilase kognitiivsetest võimetest. 
Kui senised kakskeelsete arengu uuringud Eestis on keskendunud akadeemilisele edasijõudmisele 3. ja 4. klassis, siis praeguses uuringus analüüsitakse kakskeelsete seisu võrreldes nendega koos õppivate eestikeelsetega aineõpetusele ülemineku ajal ehk 5. klassi alguses. Akadeemilist edukust hinnatakse nii matemaatika üldoskuste kui ka eesti keele, täpsemalt keele mõistmise ja tekstist arusaamise puhul.

Teadusuuringud on korduvalt kinnitanud ka seda, et akadeemilist edukust saab suurel määral prognoosida õpilase üldise vaimse võimekuse põhjal (Kuusinen \& Leskinen, 1988; Rohde \& Thompson, 2007). Seepärast ei peaks lihtsalt võrdlema eri keeletaustaga õpilaste akadeemilisi tulemusi, vaid uurima täpsemalt, mis iseloomustab neid lapsi, kes on koolis edukamad. Lisaks on mõttekas analüüsida võimekuse ja akadeemilise edasijõudmise seoseid just arenguliselt, st selle asemel et vaadata, kuidas baasvõimekus ennustab sama aasta tulemusi akadeemilises plaanis, võiks hoopis uurida lapse võimete realiseerumist edaspidistes õpitulemustes. See võimaldab hinnata koolikeskkonna efektiivsust - seda, kuidas suudetakse lapse võimekust akadeemilise edukuse huvides ära kasutada (Toomela, Kikas, \& Mõttus, 2006).

Siinses uurimuses keskendutaksegi vaimse võimekuse ja akadeemilise edukuse seoste analüüsile nii kakskeelsete kui ka eestikeelsete valimi põhjal. Teisisõnu, uuritakse, kuidas realiseeruvad õpilase vaimsed baasvõimed tema edaspidises akadeemilises edukuses ning millised on erineva IQ tasemega eesti- ja kakskeelsete arengumustrid aineõpetusele üleminekul. Varasematele uurimustele toetudes eeldatakse, et kakskeelsete rühma kui terviku tase on ükskeelsete rühmaga võrreldes madalam nii matemaatikas kui ka eesti keele mõistmises. Uurimuses täpsustatakse, kas see tendents iseloomustab ühtmoodi kõiki kakskeelseid või on see iseloomulik vaid osale võõrkeeles õppijaile.

\section{Klassi õpikeskkonna mõju õpilase akadeemilisele edukusele}

Kakskeelsuse ja akadeemilise edukuse seose uuringud keskenduvad peamiselt õpilase personaalsetele omadustele, nt madalamale keeleoskustasemele ja kognitiivsete võimete erinevustele (Bialystok, 1988; Bialystok \& Majumder, 1998; Bialystok \& Viswanathan, 2009; Kempert et al., 2011; Kikas, 2012; Vuorenkoski, Kuure, Moilanen, Penninkilampi, \& Myhrman, 2000). Vähem on teada, millist mõju avaldavad õpikeskkonna tegurid kakskeelsete arengule (nt Carreker et al., 2007; Seepter, 2012; Özerk, 2001). Seepärast oleks huvitav uurida, milline on õpikeskkonna osa kakskeelsete akadeemilises arengus. 
Kaasõpilaste rühma mõju lapse akadeemilisele arengule on uuritud juba mõnda aega (Hooper \& Hannafin, 1988; Lou et al., 1996; Slavin, 1987). Uuringute põhjal võib väita, et kaasõpilaste vaimsete võimete mõju lapse õpitulemustele sõltub õpilase enda vaimsete võimete tasemest (Lou et al., 1996). Lou ja tema kolleegid leidsid, et vaimselt vähem võimekad lapsed näitasid paremaid tulemusi heterogeenses rühmas, kus oli võimetelt nendega sarnaseid lapsi ja ka palju võimekamaid lapsi, seevastu keskpärase vaimse potentsiaaliga õpilased saavutasid paremaid tulemusi homogeenses rühmas. Vaimselt võimekatel õpilastel polnud rühma taust nende õppimistulemuste seisukohalt määrav: nende sooritus oli ühtviisi hea nii homogeenses kui ka heterogeenses rühmas. Seepter (2010) on uurinud, kuidas eestikeelsete õpilaste vaimsed võimed 3. klassis realiseeruvad 4. klassi matemaatika tulemustes ning kuidas need arengumustrid väljenduvad eri tüüpi klassikombinatsioonides, võttes arvesse klassikaaslaste keskmist IQ taset ja selle varieeruvust. Indiviiditasandi analüüs (konfiguratsiooniline sagedusanalüüs) näitas, et kaasõpilaste mõju indiviidi akadeemilisele edukusele on keerulisem, kui senistest uuringutest on selgunud. Uuringust selgus kolm klassikaaslaste õpikeskkonda, mis seostusid oluliselt õpilase akadeemilise arenguga: keskmisest kõrgema võimekuse tasemega, kuid siiski mõõdukalt varieeruvate võimetega taust, ühtlane, kuid keskmisest madalama võimekuse tasemega taust ja keskmisest kõrgema võimekuse tasemega, kuid heterogeenne klassikaaslaste võimete taust. Tulemused ei võimaldanud üheselt väita, et madala IQ tasemega õpilastele mõjub stimuleerivalt vaid võimekuse poolest heterogeense rühma taust, sest positiivset mõju täheldati ka homogeense rühma puhul, kus kaasõpilaste võimekuse tase oli keskmisest madalam. Lisaks selgus uuringust, et rühmaefekt avaldab negatiivset mõju võimekamate õpilaste matemaatikasooritusele. Nimelt leiti üks õpikeskkond - heterogeenne, kuid keskmisest kõrgema võimekuse tasemega klassikaaslased -, kus esines märkimisväärne hulk neid võimekaid õpilasi, kelle potentsiaal matemaatikas ei realiseerunud.

Teine $\mathrm{nn}$ võimekusrühmitamise (ability grouping) uurimissuund püüab välja selgitada kaasõpilaste mõju taga peituvaid põhjusi. Need võivad tuleneda nii õpetajast (Gamoran, 1986; Lou, Abrami, \& Spence, 2000) kui ka klassikaaslastest endist, täpsemalt rühmatöö protsessist (Cheng, Lam, \& Chan, 2008). Gamoran (1986) on väitnud, et ühtlase tasemega rühmas on õpetaja tegevus, st juhiste andmise kvaliteet, õpilase akadeemilise tulemuse peamine ennustaja. Nimelt võttes arvesse õpilaste võimeid ja teadmiste taset, on õpetajal võimete poolest homogeenses rühmas lihtsam anda juhiseid kõigile õpilastele kui heterogeense 
võimete tasemega rühmas. Samas ühtlaselt madala võimete tasemega rühmas võivad õpitulemused olla kehvad just sel põhjusel, et õpetaja ei anna õpilastele arendavaid ülesandeid ja õpetaja juhendustöö on samuti nõrk (Lou et al., 2000). Teised teadlased on keskendunud õppeprotsessi ajal toimuva õpilastevahelise suhtluse analüüsile (Cheng et al., 2008) ja on leidnud, et õpilase akadeemilist tulemust mõjutab see, kuidas õpilased lahendavad rühmas ülesandeid, mitte pelgalt rühma võimete taust. Samas on selge, et selline mitmekülgset arengut pakkuv rühmatöö, kus edasiminekut võib täheldada nii nõrga kui ka tugeva potentsiaaliga õpilastel, on piisavalt keeruline ning vajab teadlikku suunamist ja juhendamist. Seega on õpetaja tegevus nii või teisiti oluline - ka õpilaste rühmatöö juhendamisel ja suunamisel.

Uurimuse üks eesmärke oli analüüsida, kuidas arenevad erineva vaimsete võimete tasemega õpilased - koos õppivad eesti- ja kakskeelsed kindlates klassi õpikeskkondades ning kas arengumustrid lapse IQ ja akadeemiliste tulemuste vahel (eraldi üks- ja kakskeelsetel) tulevad esile kindlates klassikeskkondades. Eelnevate uuringute taustal võib eeldada, et nõrga potentsiaaliga õpilased arenevad heterogeensete võimete tasemega rühmas paremini (Lou et al., 1996; Seepter, 2010), kuid ka homogeenselt madala vaimse tasemega klassi õpikeskkonnas võib näha vähem võimekate õpilaste arengut (Seepter, 2010). Seevastu keskpärase ja tugeva vaimse potentsiaaliga õpilased saavutavad võimetekohaseid või paremaid akadeemilisi tulemusi ühtlasema tasemega rühmas (Lou et al., 1996; Seepter, 2010). Lisaks pakub eksploratiivsest aspektist huvi, kas kakskeelsete arengu ja klassi õpikeskkonna vahel esinevad ükskeelsetega sarnased seosed.

Varasemate uuringute põhjal võib eeldada, et peale klassikaaslaste võimete tausta on oluline õpilase akadeemilise tulemuslikkuse ennustaja ka see, kuidas õpetaja tuleb erinevate võimetetaustaga klassikomplektidega üldiselt toime (Gamoran, 1986; Lou et al., 2000).

\section{Meetod}

\section{Valim}

Uuringus osales kokku 16 eesti õppekeelega kooli Tartust, Tallinnast, Pärnust, Harjumaalt, Jõgevamaalt, Ida- ja Lääne-Virumaalt. Neis koolides õppisid koos eesti- ja kakskeelsed õpilased. Kakskeelseteks õpilasteks on liigitatud lapsed, kelle kodus kõneletakse õppekeelest erinevat keelt - vene keelt (või eesti keelt koos vene keelega). See tähendab, et need lapsed peavad toime tulema kahes keelekeskkonnas: nad õpivad eesti keeles, aga väljas- 
pool kooli puutuvad kokku venekeelse keskkonnaga. Samas ei peegelda selline rühmajaotus laste keeleoskustaset ei eesti ega ka vene keele puhul.

Uuringus osales kokku 323 eestikeelset ja 175 kakskeelset õpilast. Lisaks oli valimis 39 õpilast, kelle kodukeel oli määramata või kes olid kakskeelsed, kelle kodukeeleks oli vene keelest erinev võõrkeel (nt itaalia, soome, inglise keel). Neid õpilasi, kes võtsid eri aastatel testimisest osa, oli testide arvestuses erinev arv (esitatud konkreetsete analüüside valimi numbris). Uuringus koguti ühelt ja samalt valimilt kolme aasta vältel 193 ja 194 eestikeelse lapse ning 112 ja 104 kakskeelse lapse tulemused vastavalt matemaatikas ja eesti keeles. Ülejäänud osa lastest ei saanud kaasata arengu-uuringusse erinevatel põhjustel. Nende hulgas oli lapsi, kel puudusid ühe aasta testi tulemused (nad olid siinse valimi mõttes uustulnukad või puudusid testimispäevadel koolist), või lapsed, keda vanemad ei lubanud uuringusse kaasata.

\section{Mõõtmisvahendid}

Akadeemiline edukus. Matemaatika edukuse mõõtmiseks kasutati 3., 4. ja 5. klassi matemaatika aineteste (koost. A. Palu, Tartu Ülikooli sotsiaal- ja haridusteaduskond), mis olid koostatud vastavuses vanuseastme õppekava nõudmistega (Vabariigi Valitsus, 2007). Matemaatikatestid võimaldasid hinnata matemaatikaoskusi TIMMS 2007 (Trends in International Mathematics and Science Study 2007) järgi kirjeldatud kolmes valdkonnas: teadmised, rakendamine ja järeldamine (Gonzales et al., 2008). Õpilase õiged vastused summeeriti eraldi igal aastal ja saadi kolm näitajat matemaatikas. Matemaatika ainetestide kirjeldavad statistikud on toodud tabelis 1.

Tabel 1. Matemaatika ja eesti keele (mõistmise osa) ainetestide kirjeldavad statistikud 3., 4. ja 5. klassis

\begin{tabular}{l|c|c|c|c|c}
\hline \multirow{2}{*}{ Valim } & \multicolumn{5}{|c}{ Matemaatika ainetest, 3., 4. ja 5. klass } \\
\cline { 2 - 6 } & $\boldsymbol{N}$ & Min-max & $\boldsymbol{M}$ & SD & Ül arv \\
\hline Eestikeelsed, 3. kl & 193 & $1-15$ & 11,64 & 2,32 & 15 \\
Kakskeelsed, 3. kl & 112 & $4-15$ & 10,21 & 2,53 & 15 \\
\hline Eestikeelsed, 4. kl & 193 & $0-10$ & 5,42 & 2,08 & 10 \\
Kakskeelsed, 4. kl & 112 & $0-9$ & 4,96 & 1,97 & 10 \\
\hline Eestikeelsed, 5. kl & 193 & $3-35$ & 27,79 & 5,48 & 36 \\
Kakskeelsed, 5. kl & 112 & $12-36$ & 26,39 & 5,14 & 36 \\
\hline
\end{tabular}




\begin{tabular}{l|c|c|c|c|c}
\hline \multirow{2}{*}{ Valim } & \multicolumn{5}{|c}{ Matemaatika ainetest, 3., 4. ja 5. klass } \\
\cline { 2 - 6 } & $\boldsymbol{N}$ & Min-max & $\boldsymbol{M}$ & SD & Ül arv \\
\hline & \multicolumn{5}{|c}{ Eesti keele ainetest - mõistmise osa, 3., 4. ja 5. klass } \\
\hline Eestikeelsed, 3. kl & 194 & $0-7$ & 5,53 & 1,53 & 8 \\
Kakskeelsed, 3. kl & 104 & $0-7$ & 3,95 & 2,2 & 8 \\
\hline Eestikeelsed, 4. kl & 194 & $0-5$ & 3,39 & 1,31 & 7 \\
Kakskeelsed, 4. kl & 104 & $0-5$ & 2,03 & 1,5 & 7 \\
\hline Eestikeelsed, 5. kl & 194 & $1-8$ & 6,2 & 1,67 & 8 \\
Kakskeelsed, 5. kl & 104 & $0-8$ & 4,85 & 2,48 & 8 \\
\hline
\end{tabular}

Märkus. Ül arv - ülesannete arv testis.

Eesti keele edukust mõõdeti 3., 4. ja 5. klassi eesti keele ainetesti mõistmise osaga (koost. K. Uibu, Tartu Ülikooli sotsiaal- ja haridusteaduskond). Eesti keele testide loomisel lähtuti Bloomi (1971) hierarhilisest taksonoomiast, õppekava nõudmistest vastavas vanuseastmes (Vabariigi Valitsus, 2007) ja riiklikest tasemetöödest. Ainetestid eeldasid erinevate mõtlemisoskuste kasutamist: tekstist arusaamist, faktide ja reeglite meelespidamist ja meenutamist ning omandatud teadmiste rakendamist. Siinses artiklis analüüsiti ainult tekstist arusaamise osa. Õiged vastused summeeriti iga aasta kohta eraldi ja saadi eesti keele teadmiste skoor (eraldi teksti mõistmise osas). Eesti keele mõistmise kirjeldavad statistikud on toodud tabelis 1 . Akadeemilisi teste täideti õppekeeles, seega kakskeelsed õpilased täitsid neid eesti keeles.

Vaimsed võimed. Üldiste vaimsete võimete mõõtmiseks kasutati Raveni progresseeruvate maatriksite testi (Raven, 1981) D-osa, mis oli kohandatud eesti keele keskkonda (Lynn, Pullmann, \& Allik, 2003). Testiga mõõdetakse järeldamisvõimet mitteverbaalsete ülesannete kaudu. Test koosneb 12 maatriksülesandest, mis on järjestatud raskusastmelt keerulisemaks. Lapsele näidati arvutiekraanil pilti kujundijadadega, millest puudus üks osa. Lapse ülesanne oli valida puuduv tükk 8 vastusevariandi seast, mis paiknesid ülesande all. Õigete vastuste hulk summeeriti ja saadi üldine vaimsete võimete skoor. Oluline on märkida, et kakskeelsed õpilased said valida testi täitmisel keele, milles nad end kodusemalt tundsid. Nii tagati olukord, et lapse kognitiivsete võimete tulemust ei mõjutanud keelefaktor. Raveni testi kirjeldavad statistikud - sooritanute arv, tulemuste varieeruvus, keskmine tulemus ja standardhälve - on toodud 
tabelis 2. Testi usaldusväärsuse näitaja (Cronbachi $\alpha=0,92$ nii kakskeelsete kui ka eestikeelsete valimil) oli väga hea.

Tabel 2. Eesti- ja kakskeelsete rühma vaimsete võimete testi kirjeldavad statistikud 3. klassis

\begin{tabular}{l|c|c|c|c}
\hline \multirow{2}{*}{ Valim } & \multicolumn{4}{|c}{ Vaimsete võimete test - Raveni D-test, 3. klass } \\
\cline { 2 - 5 } & $\boldsymbol{N}$ & Min-max & $\boldsymbol{M}$ & SD \\
\hline Eestikeelsed & 234 & $0-11$ & 4,59 & 3,15 \\
Kakskeelsed & 132 & $0-10$ & 3,72 & 3,18 \\
\hline
\end{tabular}

Klassi öpikeskkond. Klassi õpikeskkonda mõõdeti kahe tunnuse alusel. Esiteks, klassi keskmine vaimne võimekus arvutati ühes klassis koos õppivate laste Raveni testi tulemuste põhjal. Näitaja varieerus klassiti, jäädes vahemikku 2,24-5,87 punkti $(M=4,13, S D=1,06)$. Teine näitaja oli klassi vaimsete võimete heterogeensus, mille arvestamisel lähtuti Raveni testi klassi keskmisest tulemusest. Nimelt oli klassi võimete taseme hajuvusnäitajaks klassi standardhälve ehk keskmine kõrvalekalle klassi keskmisest võimete tulemusest (vahemikus 1,41-3,97 punkti; $M=2,99, S D=0,56$ ). Mida suurem oli näitaja, seda erinevamad on vaimsete võimete poolest ühes klassis õppivad õpilased.

\section{Protseduur}

Uuring korraldati kõigil aastatel septembrist detsembrini. Akadeemilised testid tehti kõigis koolides õpetajate eestvedamisel pooleteise kuu jooksul (september - 15. oktoober). Ülejäänud andmed kogusid uurimisrühma liikmed kooliga kokkulepitud nädalal.

Kõigi uuringusse lubatud laste akadeemilist edukust uuriti korduvalt kolme aasta vältel 3., 4. ja 5. klassis. Siinse artikli tarbeks keskenduti eraldi 5. klassi ainetestide tulemuste seostele lapse vaimsete võimete ja õpikeskkonna näitajatega, sest just 5 . klassis minnakse klassiõpetuselt üle aineõpetusele. Õpilase vaimsed võimed selgitati välja esimesel uurimisaastal - 3. klassis. See uurimisskeem võimaldas analüüsida lapse vaimse potentsiaali ja tema tulevase akadeemilise edukuse vahelisi seoseid.

Andmeid analüüsiti programmidega Statistica 7.0 ja SLEIPNER 2.1 (Bergman \& El-Khouri, 2002). 


\section{Tulemused}

Uurimuse eesmärk oli analüüsida, kuidas arenevad eesti koolis koos õppivad eesti- ja kakskeelsed lapsed. Selleks analüüsiti esimese sammuna eestija kakskeelsete õpilaste rühmade vahelisi erinevusi kolme aasta vältel: 3., 4. ja 5. klassis. Täpsemalt huvituti sellest, kus paiknevad kakskeelsed oma tulemustes võrreldes eestikeelsete õpilastega. Esmalt standardiseeriti akadeemiliste testide tulemused aastate kaupa järgmiselt: õpilase toortulemusest lahutati eestikeelsete õpilaste rühma keskmine tulemus ja jagati vastus eestikeelsete rühma standardhälbega. Vastuseks saadi arv, mis näitas, kus paikneb õpilase tulemus võrreldes eesti õpilaste rühma keskmise tulemusega. Tulemus "0" tähendas, et lapse teadmised on samad mis eestikeelsel rühmal keskmiselt; tulemused „üle 0i” olid eestikeelsete rühma keskmisest paremad. Kui standardiseeritud testi tulemus tuli negatiivne, tähendas see, et õpilase saavutus jäi alla eestikeelsete rühma keskmise tulemuse. Dispersioonanalüüsi (repeated measures ANOVA) tulemused näitasid, et ainevaldkonniti oli pilt erinev (joonised 1 ja 2 ).

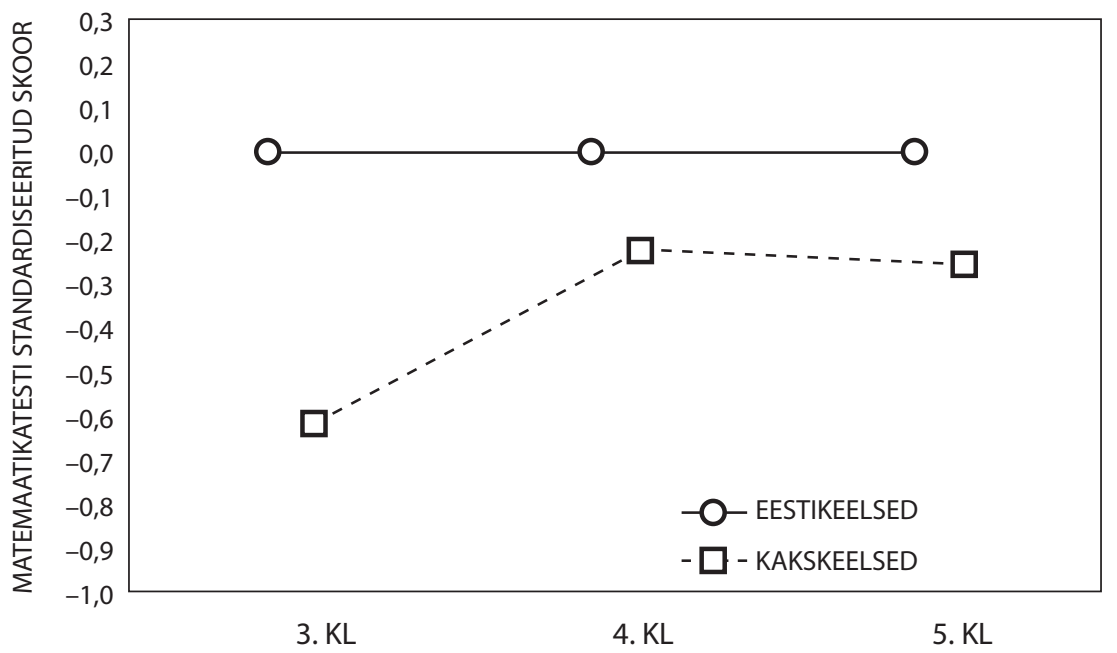

Joonis 1. Eesti- ja kakskeelsete õpilaste rühma matemaatikatesti keskmised standardiseeritud tulemused 3., 4. ja 5. klassis

3.-5. klassi võrdluse põhjal võib väita, et eesti- ja kakskeelsete õpilaste sooritused matemaatikas muutuvad aastate jooksul statistiliselt olulisel määral $F(2,606)=6,16 ; p<0,05$. Detailsem post hoc-analüüs (LSDtest) näitas, et kui 3. klassis olid eestikeelsete rühmal statistiliselt oluliselt paremad tulemused matemaatikas $(p<0,01)$, siis 4 . ja 5. klassis rühmadevahelised olulised erinevused kadusid $(p>0,05)$. 


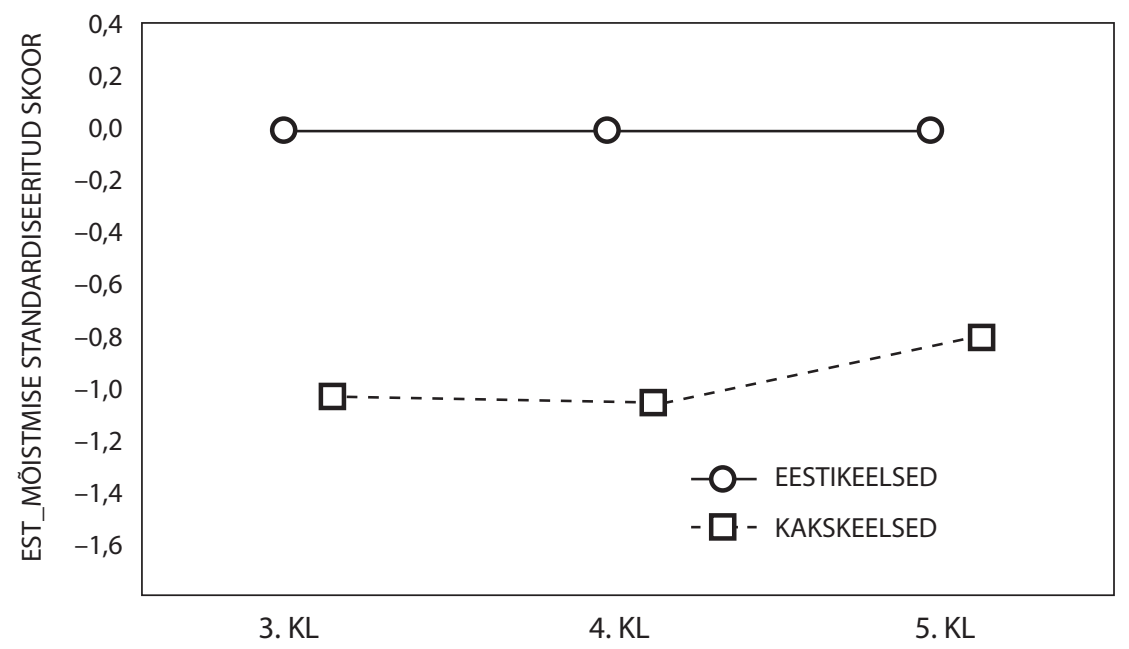

Joonis 2. Eesti- ja kakskeelsete õpilaste eesti keele mõistmise osaoskuse keskmised standardiseeritud tulemused 3., 4. ja 5. klassis

Tulemustest ilmneb, et eesti keele mõistmises rühmadevahelised erinevused aastate jooksul statistiliselt olulisel määral ei muutunud $F(2,592)=$ 1,$49 ; p>0,05$. LSD-test kinnitas, et kõigil kolmel aastal olid eestikeelsed õpilased oluliselt paremal tasemel kui kakskeelsed $(p<0,001)$.

Analüüsi põhjal võib väita, et aineõppele ülemineku ajaks (5. klassi alguseks) oli kakskeelsete õpilaste akadeemilise edukuse tase keskmiselt madalam kui samas õpikeskkonnas õppivatel eestikeelsetel lastel eesti keele mõistmises, kuid matemaatika omandamisel olid olulised erinevused 5. klassiks kadunud. See aga ei võimalda midagi öelda põhjuste kohta, st ei saa väita, et kakskeelsetel õpilastel läheb koolis kehvemini, sest nende eesti keele oskus on kehvem kui ükskeelsetel. Peale keeleoskuse võib olla mitmeid teisi tunnuseid, mille alusel võiks õpilaste rühmadevahelisi erinevusi analüüsida. Siinses uurimuses keskendutakse kahte tüüpi tunnustele: õpilase individuaalse omadusena käsitletakse tema vaimset baasvõimekust, teise tunnuse moodustab klassi õpikeskkond klassikaaslaste taust (nende keskmine IQ tase ja selle varieerumine klassis ning õpetaja üldine toimetulek selle klassikomplekti õpetamisel).

\section{Eesti- ja kakskeelsete vaimsete võimete ning ópitulemuste vaheline seos}

Uurimuse raames huvituti samuti sellest, kas akadeemilistes tulemustes säilivad rühmadevahelised erinevused ka siis, kui võtta arvesse õpilase 
vaimse võimekuse taset. Mudelid koostati skeemi järgi, mis võimaldas õpilase 3. klassi IQ näitaja ja kodukeele alusel prognoosida sooritust 5. klassi matemaatikas ja eesti keele mõistmises. Lapse kodukeele tunnus kodeeriti 0/1 süsteemi, kus väärtus „1” tähistas eestikeelset last ja väärtus „0” kakskeelset. Hulgiregressioonanalüüside tulemused on toodud tabelis 3.

Tabel 3. Õpilase vaimse baasvõimekuse ja kodukeele seos matemaatika edukusega ning eesti keele mõistmisega 5 . klassis (kaks regressioonimudelit)

\begin{tabular}{l|c|c}
\hline \multirow{2}{*}{$\begin{array}{l}\text { Sõltumatu } \\
\text { muutuja }\end{array}$} & Matemaatika, 5. kl & Eesti keel - mõistmine, 5. kl \\
\cline { 2 - 3 } & $\boldsymbol{\beta}$ & $\boldsymbol{\beta}$ \\
\cline { 2 - 3 } Baas-IQ, 3. kI & $0,31^{* * *}$ & $0,23^{* * *}$ \\
\hline Kodukeel & 0,10 & $0,32^{* * *}$ \\
\hline$N$ & 316 & 312 \\
\hline$F$ & $19,93^{* * *}$ & $32,51^{* * *}$ \\
\hline Vabadusastmed & $2 ; 313$ & $2 ; 309$ \\
\hline$R$ & 0,34 & 0,42 \\
\hline Seletusmäär & $11,30 \%$ & $17,38 \%$ \\
\hline
\end{tabular}

Märkus. *** $-p<0,0001$.

Tabelist võib näha, et koostatud mudelid on statistiliselt olulised, kirjeldades edukust matemaatikas 11\%ga ja eesti keeles 17\%ga. Andmed osutasid ka sellele, et tulemused on valdkonnaspetsiifilised. Nimelt kui võtta arvesse õpilase vaimset võimekust, siis see, kas ta on emakeeles õppija või muukeelne laps, ei avalda matemaatikateadmiste omandamisele suurt mõju. See tähendab, et võimekas laps (olenemata sellest, kas ta on eestivõi kakskeelne) saab ka matemaatikas paremaid tulemusi kui vähem võimekas laps. Eesti keele omandamisel ilmnesid teistsugused tulemused. Selgus, et peale vaimsete võimete on ka lapse kodukeel oluline näitaja tema eesti keele teadmiste omandamisel. See tähendab, et näiteks võimekas eestikeelne laps saavutab eesti keeles paremaid tulemusi võrreldes andeka kakskeelse lapsega ja vastupidi.

Järgnevalt täpsustati, kas leitud tendents eesti- ja kakskeelsete õpilaste akadeemilise edukuse erinevustes iseloomustab kogu rühma liikmeid või eksisteerib rühma sees mingi alatüüp õpilasi, kellele ülaltoodud üldine tendents ei kehti. Selle eesmärgi täitmiseks sobivad hästi 
analüüsimeetodid, kus tulemustes säilivad indiviiditi andmemustrites esinevad variatsioonid, st tulemus ei väljenda anonüümset (mitteindiviidikeskset) keskmistatud infot, mis ei pruugi kehtida kõigi rühma liikmete kohta (Indurkhya \& von Eye, 2000). Teisisõnu, kuna rühmade keskmiste mehhanismil töötavad analüüsimeetodid (nt regressioonanalüüs) ei pruugi kirjeldada piisavalt täpselt kogu rühma tervikuna, siis detailsema pildi saamiseks kasutati lisaks isikutaseme analüüsimeetodit, täpsemalt konfiguratsioonilist sagedusanalüüsi (CFA - Configurational Frequency Analysis) (von Eye, 1990). Selle meetodiga võrreldakse andmete risttabelis esinevaid jälgitud ehk tegelikke sagedusi oodatud sagedustega, mis võimaldab eristada tüüpilisi mustreid (andmekombinatsiooni esineb tegelikult oluliselt rohkem kui oodati) ja ebatüüpilisi mustreid (tegelik sagedus andmekombinatsioonis jääb oodatust oluliselt väiksemaks). See võimaldas jälgida iga üksikut andmekombinatsiooni ehk konfiguratsiooni ja teha järeldusi kõiki andmemassiivis esinevaid variante silmas pidades.

Uuringuga sooviti ka välja selgitada, kuidas erineva võimekuse tasemega õpilased - kaks- ja eestikeelsed - on kasutanud ära oma vaimset potentsiaali matemaatikas ja eesti keeles aineõppele üleminekul (5. klassi alguseks). Selleks jaotati esmalt õpilased 3. klassi vaimse võimekuse skoori alusel kolme enam-vähem võrdsesse rühma, kasutades tertsiilidega jaotust: madala, keskmise ja kõrge võimete tasemega õpilased. Sarnane jaotusprotseduur tehti ka ópilaste 5. klassi matemaatika ainetesti ja eesti keele mõistmise tulemustega ning õpilased jaotati akadeemilise edukuse järgi madala, keskmise ja kõrge tasemega rühmadesse. Nende kahe tunnuse alusel saadi üheksa arengutrajektooriga mustrit ehk kombinatsiooni lapse 3. klassi vaimse baasvõimekuse rühma ja 5. klassi matemaatika rühma või 5 . klassi eesti keele rühma vahel ja need tähistati järgmiselt: 1 - madal võimekuse tase ja madal edukuse tase; 2 - madal võimekuse tase ja keskmine edukuse tase; 3 - madal võimekuse tase ja kõrge edukuse tase; 4 - keskmine võimekuse tase ja madal edukuse tase; 5 - keskmine võimekuse tase ja keskmine edukuse tase; 6 - keskmine võimekuse tase ja kõrge edukuse tase; 7 - kõrge võimekuse tase - madal edukuse tase; 8 - kõrge võimekuse tase - keskmine edukuse tase ja 9 kõrge võimekuse tase - kõrge edukuse tase (rühmade suurused keelte kaupa on näha tabelis 4). Seejärel moodustati risttabel $9 \times 2$ (vaimsete võimete ja akadeemilise edukuse rühma kombinatsiooni ning õppekeele rühma vahel ning seda eraldi matemaatika ja eesti keele puhul) ning analüüsiti tulemusi CFAga, kasutades programmi SLEIPNER 2.1. Tulemused on toodud tabelis 4 . 
Tabel 4. Kaks CFA tulemust: tegelik sagedus, oodatud sagedus; $p$-väärtus iga konfiguratsiooni kohta lapse 3. klassi vaimsete võimete rühma ja 5. klassi akadeemilise testi soorituse rühma kombinatsioonide ning keelerühma vahel

\begin{tabular}{|c|c|c|c|c|c|}
\hline \multicolumn{2}{|c|}{ Õpilase areng } & \multicolumn{2}{|c|}{ Matemaatika, 5. kl } & \multicolumn{2}{|c|}{ Eesti keel - mõistmine, $5 . \mathbf{k l}$} \\
\hline $\begin{array}{l}\text { Baasvõimed, } \\
\text { 3. kl }\end{array}$ & $\begin{array}{l}\text { Ainetest, } \\
5 . \mathrm{kl}\end{array}$ & Eestikeelsed & Kakskeelsed & Eestikeelsed & Kakskeelsed \\
\hline Madal & Madal & $\begin{array}{c}15 \\
14,96 \\
n s\end{array}$ & $\begin{array}{c}16 \\
8,79 \\
<0,05\end{array}$ & $\begin{array}{c}14 \\
13,17 \\
n s\end{array}$ & $\begin{array}{c}20 \\
7,58 \\
<0,001\end{array}$ \\
\hline Madal & Keskmine & $\begin{array}{c}16 \\
17,00 \\
n s\end{array}$ & $\begin{array}{c}12 \\
10,00 \\
n s\end{array}$ & $\begin{array}{c}7 \\
10,63 \\
n s\end{array}$ & $\begin{array}{c}9 \\
6,12 \\
n s\end{array}$ \\
\hline Madal & Kõrge & $\begin{array}{c}8 \\
17,79 \\
<0,01\end{array}$ & $\begin{array}{c}11 \\
10,46 \\
n s\end{array}$ & $\begin{array}{c}18 \\
25,70 \\
=0,06\end{array}$ & $\begin{array}{c}10 \\
14,80 \\
n s\end{array}$ \\
\hline Keskmine & Madal & $\begin{array}{c}22 \\
21,01 \\
n s\end{array}$ & $\begin{array}{c}19 \\
12,36 \\
<0,05\end{array}$ & $\begin{array}{c}13 \\
18,57 \\
n s\end{array}$ & $\begin{array}{c}17 \\
10,69 \\
<0,05\end{array}$ \\
\hline Keskmine & Keskmine & $\begin{array}{c}21 \\
23,89 \\
n s\end{array}$ & $\begin{array}{c}13 \\
14,05 \\
n s\end{array}$ & $\begin{array}{c}19 \\
14,99 \\
n s\end{array}$ & $\begin{array}{c}8 \\
8,63 \\
n s\end{array}$ \\
\hline Keskmine & Kõrge & $\begin{array}{c}30 \\
25,00 \\
n s\end{array}$ & $\begin{array}{c}6 \\
14,70 \\
<0,01\end{array}$ & $\begin{array}{c}41 \\
36,25 \\
n s\end{array}$ & $\begin{array}{c}12 \\
20,27 \\
<0,05\end{array}$ \\
\hline Kõrge & Madal & $\begin{array}{c}10 \\
23,85 \\
<0,001\end{array}$ & $\begin{array}{c}12 \\
14,03 \\
n s\end{array}$ & $\begin{array}{c}6 \\
20,36 \\
<0,001\end{array}$ & $\begin{array}{c}13 \\
12,05 \\
n s\end{array}$ \\
\hline Kõrge & Keskmine & $\begin{array}{c}31 \\
27,12 \\
n s\end{array}$ & $\begin{array}{c}15 \\
15,94 \\
n s\end{array}$ & $\begin{array}{c}17 \\
16,90 \\
n s\end{array}$ & $\begin{array}{c}7 \\
9,73 \\
n s\end{array}$ \\
\hline Kõrge & Kõrge & $\begin{array}{c}45 \\
28,37 \\
<0,01\end{array}$ & $\begin{array}{c}13 \\
16,68 \\
n s\end{array}$ & $\begin{array}{c}63 \\
40,86 \\
<0,001\end{array}$ & $\begin{array}{c}18 \\
23,53 \\
n s\end{array}$ \\
\hline KOK & & 198 & 117 & 198 & 114 \\
\hline
\end{tabular}

Märkus. Igas lahtris on toodud tegelik sagedus, oodatud sagedus ja $p$-väärtus iga konfiguratsiooni kohta. $n s$ - pole statistiliselt oluline. Tüüp on esitatud poolpaksus kirjas ja antitüüp poolpaksus kaldkirjas. 
Esiteks on tabelist näha, et mustrid lapse arengupotentsiaali ja akadeemiliste tulemuste vahel olid üldiselt ainevaldkonniti sarnased: need ilmnesid ühtmoodi nii matemaatikas kui ka eesti keele mõistmises. Teiseks jaotusid lapsed rühmadesse nii ootuspäraselt kui ka mitteootuspäraselt. Ootuspärased seosed olid need, mis avaldusid ka regressioonanalüüsil - madala võimekuse tasemega õpilased saavad ka halvemaid akadeemilisi tulemusi ja vastupidi. Tabelist on näha, et kakskeelsete vähene akadeemiline areng vastas potentsiaalile ning suure potentsiaaliga eestikeelsetel õpilastel olid ka suured skoorid ainetestides. Samas ilmnesid mitteootuspärased seosed, mis regressioonanalüüsi tulemustes jäid varjatuks. Nimelt eristus rühm keskpärase võimekusega kakskeelseid, kelle õpitulemused olid halvemad, kui võiks nende vaimse võimekuse näitaja alusel eeldada. Teisisõnu tuli kakskeelsete hulgas esile riskirühm - keskpärase võimekusega õpilased. Need moodustasid 46-50\% keskpärase IQga kakskeelsetest. Nende potentsiaal akadeemilises plaanis ei realiseerunud ei matemaatikas ega eesti keele mõistmises.

Seega selgus CFA abil, et madalam akadeemilise edukuse tase aineõpetuse perioodi alguses ei iseloomusta ühtmoodi kõiki muukeelseid õpilasi. Võimekusele mittevastav madalam akadeemiline tase on iseloomulik just keskpärase võimekusega kakskeelsetele lastele ja seda mõlemas aines - nii matemaatikas kui ka eesti keele mõistmises. Seega võib öelda, et CFA tulemus täpsustas oluliselt regressioonanalüüsi tulemust ja selgusid õpilaste rühmad, kus probleemid esinevad. Just keskpäraste kakskeelsete õpilaste akadeemiline edasijõudmine on problemaatiline, mistõttu tuleks need lapsed õpetajal ära tunda ning neile tähelepanu pöörata, et toetada nende akadeemilist arengut.

\section{Klassi õpikeskkond - klassikaaslaste vaimsete võimete mõju ópilase akadeemilisele arengule eesti- ja kakskeelsete puhul}

Uurimuse üks eesmärkidest oli analüüsida, kuidas arenevad erineva vaimsete võimete tasemega õpilased - eesti- ja kakskeelsed - kindlates klassi õpikeskkondades. Klassi õpikeskkonna tunnusena käsitleti kaasõpilaste keskmist vaimsete võimete taset ja selle varieeruvust. Täpsemalt küsiti, kas selgunud arengumustrid lapse IQ ja akadeemiliste tulemuste vahel tulevad esile kindlates klassikeskkondades. Selleks jaotati klassikomplektid esmalt tertsiilide alusel kolme võrdsesse rühma, lähtudes klassi keskmise vaimse võimekuse tasemest, ning saadi madala, keskmise ja kõrge keskmise võimekuse tasemega klassid. Teisalt jagati klassikomplektid kolme rühma klassi keskmiste võimete varieeruvuse alusel, saades homogeensed 
ehk võimete poolest ühtlased klassid, mõõdukalt varieeruvate võimetega õpilaste klassid ning heterogeensed ehk ebaühtlase võimete tasemega õpilaste klassid. Nende kahe klassi õpikeskkonna tunnuse alusel moodustati üheksa kombinatsiooni ehk üheksa õpikeskkonda. Seejärel koostati $9 \times 9 \times 2$ risttabel, mis sisaldas üheksat arengumustrit ópilase IQ taseme rühma ja akadeemilise edasijõudmise rühma kombinatsioonist (üheksas klassi õpikeskkonnas), seda eesti- ja kakskeelsete õpilaste puhul eraldi. Tabelid koostati nii matemaatika soorituse kui ka eesti keele mõistmise tulemuse kohta. Tulemusi analüüsiti konfiguratsioonilise sagedusanalüüsiga, mis on toodud tabelites 5 ja 6 .

Tabelitesse 5 ja 6 on koondatud viit tüüpi klassi õpikeskkonna tulemused, sest nendes avaldusid olulised seosed õpilase vaimse potentsiaali ja akadeemilise edukuse vahel. See tähendab, et andmekombinatsioonides eristusid tüübid, mida esines oodatud sagedusest oluliselt rohkem. Need klassi õpikeskkonna tüübid hõlmasid 84\% koolimaastiku klassikomplektidest. Seega 16\% klassikomplektidest jäi õpilase arengu seisukohalt praegu kirjeldamata, sest neid õpikeskkondi oli vähem: praegusel valimil vaid üks klassikomplekt ühe õpikeskkonna näitena. See ei võimaldanud seostel esile tulla ja seeläbi laiapõhjalisemaid järeldusi teha.

Tabelitest on näha, et ainevaldkonniti on tulemused üldiselt sarnased. See tähendab, et klassikaaslaste mõju eesti- ja kakskeelsete õpilaste tulemustele ilmnes ühtviisi nii matemaatikas kui ka eesti keele mõistmises.

Eristusid viis klassi õpikeskkonda. Esimene klassikeskkond moodustus klassidest, kus õppisid keskmisest madalama IQ tasemega õpilased, kuid kelle keskmine võimete tase oli ühtlane (20\% klassikomplektidest). Neis klassikomplektides õppis 15\% õpilastest.

Selles õpikeskkonnas ilmnes kolm mustrit. Esiteks, suur osa madala võimekuse tasemega eestikeelsetest õpilastest (75\%) näitas matemaatikas vastavalt potentsiaalile halvemat tulemust. Teiseks, valdav osa madala võimekuse tasemega kakskeelsetest arenes ja näitas nii matemaatikas (75\%) kui ka eesti keele mõistmises (56\%) ootuspärasest paremat tulemust. Kolmandaks, 71\% keskpärase IQ tasemega kakskeelsete laste õpitulemustest olid halvemad, kui nende vaimse võimekuse näitajate alusel oleks võinud eeldada, seda nii eesti keele mõistmises kui ka matemaatikas. 


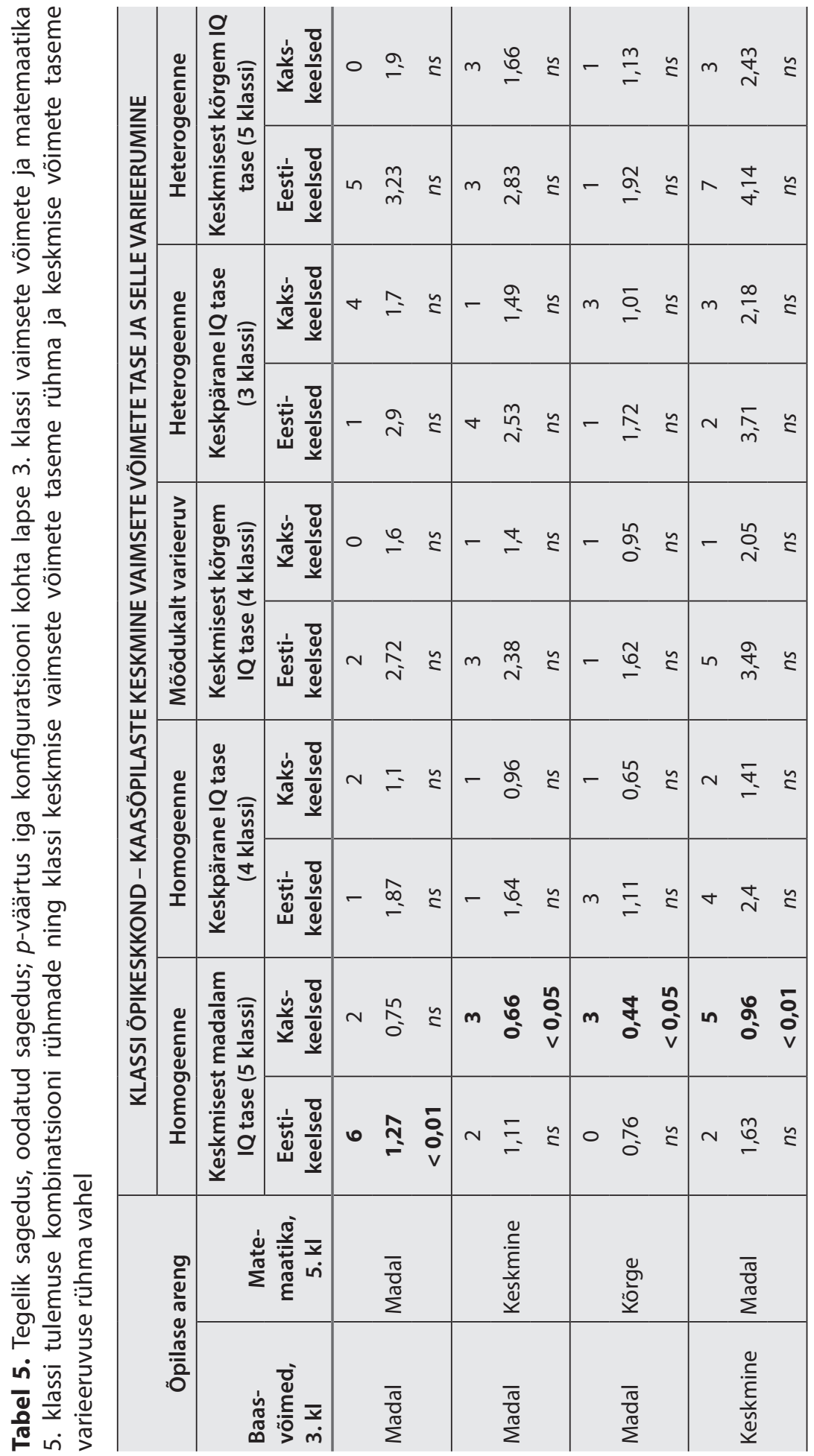




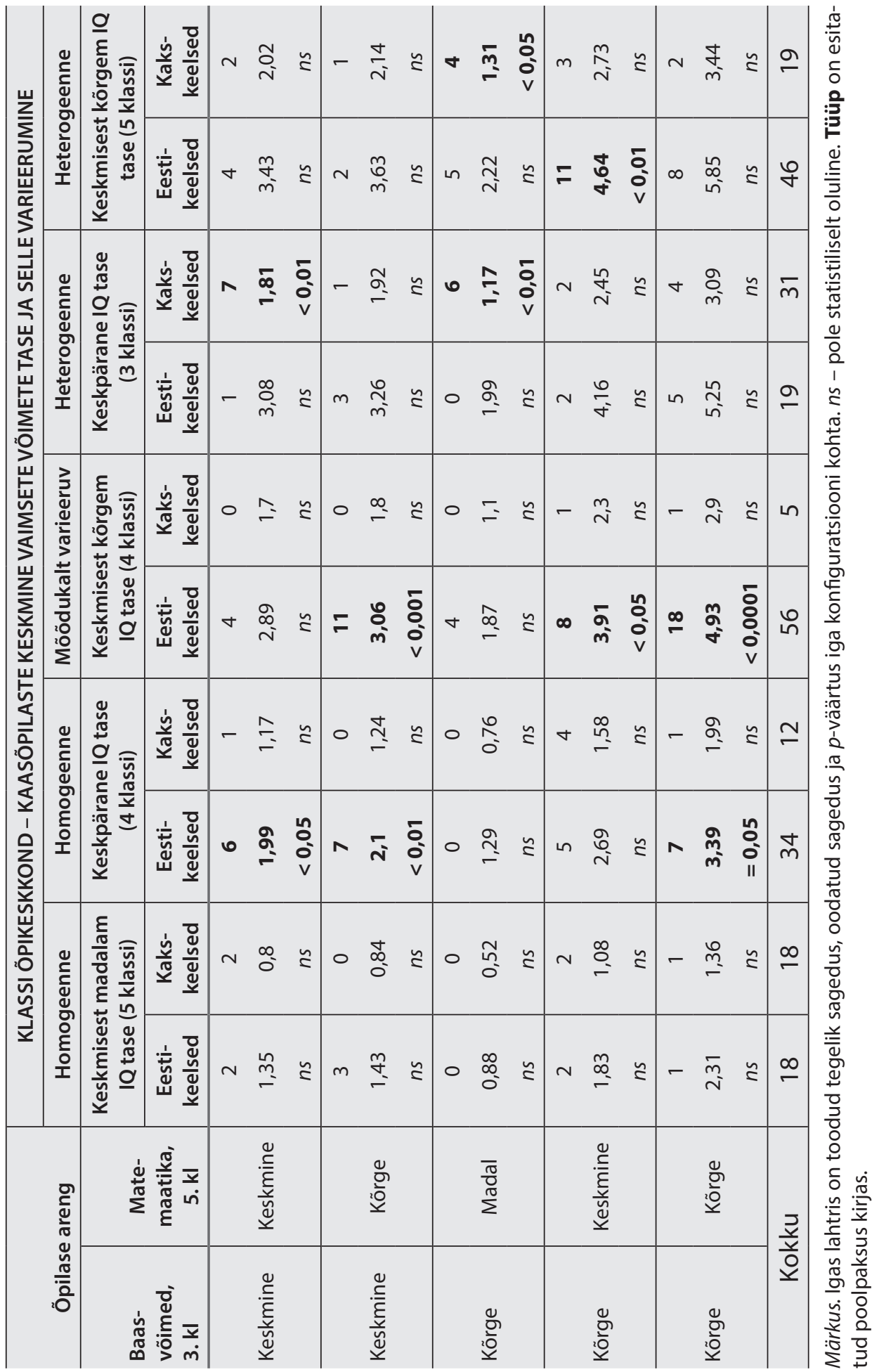




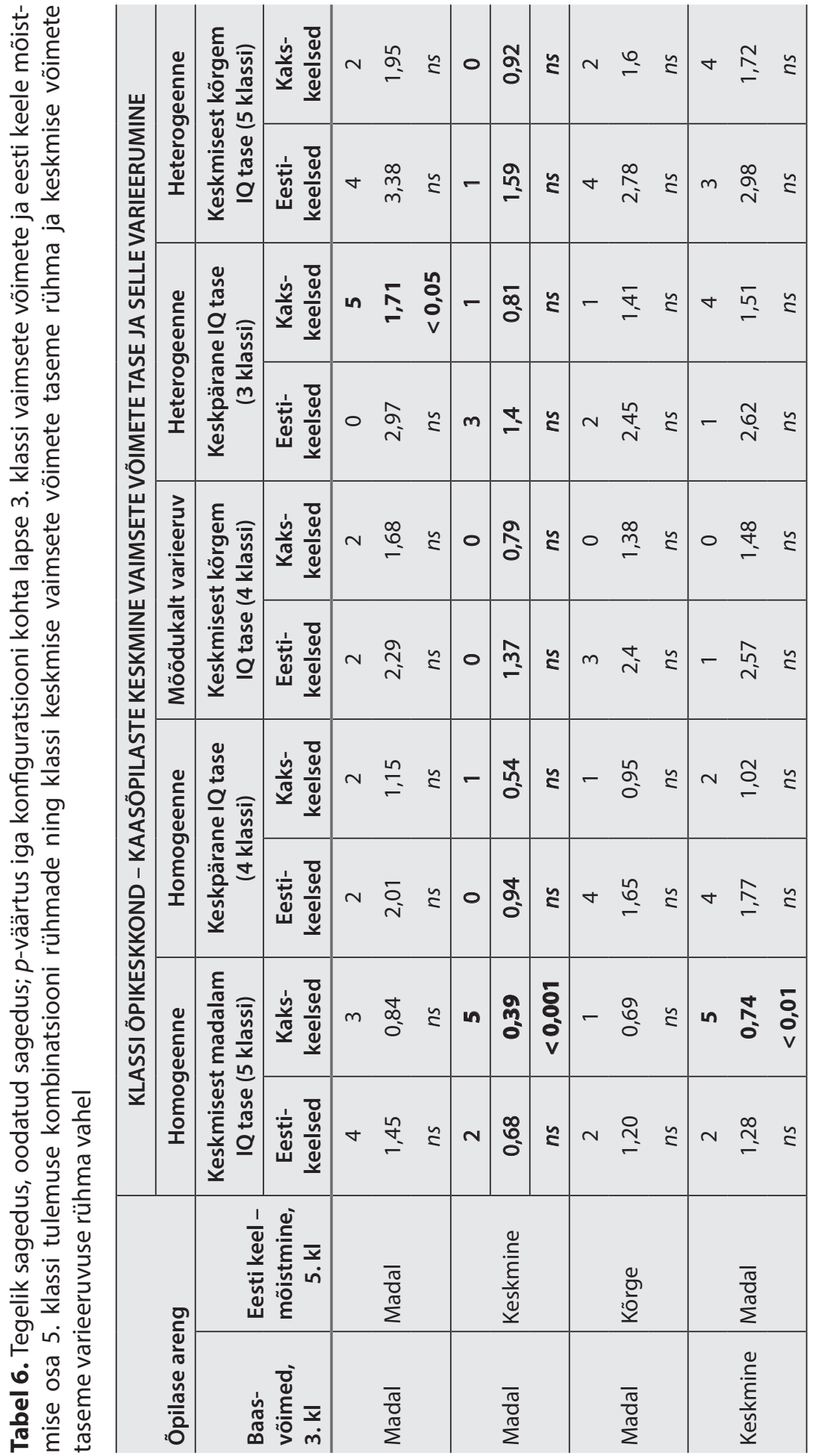




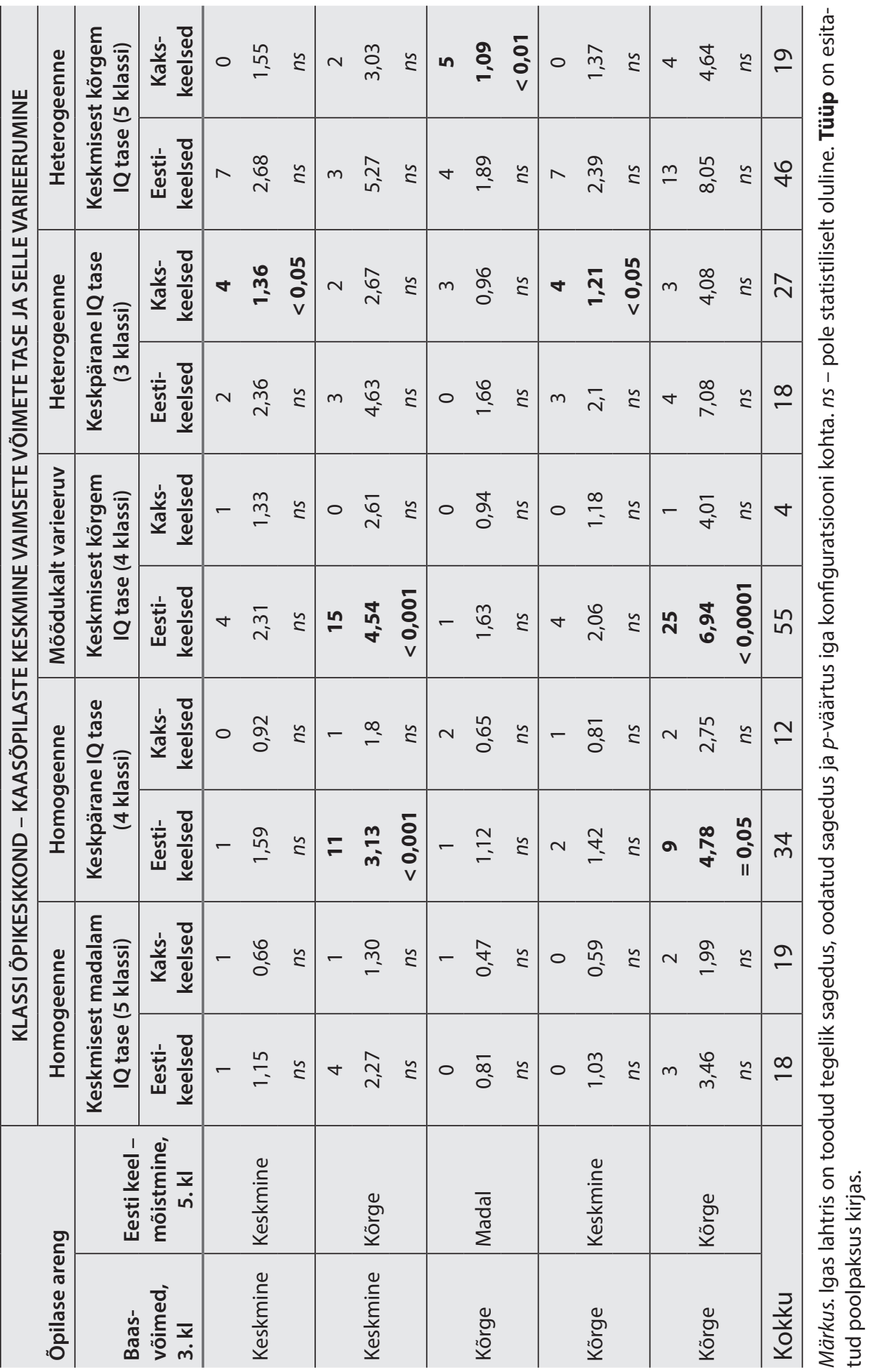


Teine klassikeskkond moodustus klassidest, kus õppisid ühtlaselt keskpärase võimekusega lapsed (16\% klassikomplektidest). Seal õppis $16 \%$ õpilastest. See õpikeskkond oli iseloomulik klassidele, mis koosnesid suuremas osas eestikeelsetest õpilastest. Eristus kaks mustrit. Esiteks, kuigi ootuspäraselt oli näha, et 35\% keskpärase IQga eestikeelsetest lastest näitas ka matemaatikas keskpärast tulemust, oli siiski märkimisväärne hulk neid keskpärase võimekusega eestikeelseid lapsi (41\%), kes sooritasid matemaatikatestid üle ootuste hästi. Sama seos ilmnes eesti keele mõistmises 69\% keskmise IQ tasemega eestikeelsete õpilaste puhul. Teiseks oli tüüpiline, et keskmisest võimekamad eestikeelsed lapsed näitasid potentsiaalile vastavaid akadeemilisi tulemusi (58\% matemaatikas ja $75 \%$ eesti keele mõistmises).

Kolmas klassikeskkond hõlmas klasse, kus õpilaste võimekus varieerus mõõdukalt, kuid klassi keskmine IQ tase oli keskmisest kõrgem (16\% klassikomplektidest). Sellesse õpikeskkonda kuulus 19\% õpilastest, kes olid enamjaolt eestikeelsed, kakskeelseid oli üksikuid. Tüüpiline muster ilmnes keskpärase IQga eestikeelsete hulgas, kellest märkimisväärne osa saavutas nii matemaatikas (55\%) kui ka eesti keeles (75\%) potentsiaaliga võrreldes paremaid tulemusi. Samas suure potentsiaaliga eestikeelsete puhul ilmnes kaks tüüpilist mustrit. Nimelt oli matemaatikas näha, et kuigi suur osa neist õpilastest $(60 \%)$ sai ka potentsiaalile vastavaid häid tulemusi, esines märkimisväärne hulk andekaid (26\%), kelle vaimne potentsiaal matemaatikas ei realiseerunud. Eesti keele mõistmise puhul ilmnes, et enamik (83\%) realiseeris oma potentsiaali ka akadeemilises plaanis.

Neljas klassikeskkond esindas klasse, kus õppisid väga erinevate võimetega lapsed (heterogeensed klassid), kuid võimete keskmine tase klassis oli siiski keskpärane (12\% klassikomplektidest). Seal õppis 13\% õpilastest. See õpikeskkond oli iseloomulik rohkem kakskeelsetele õpilastele. Tulemustest selgus, et suur osa kõrge IQ tasemega kakskeelsetest ei saavutanud ootuspäraseid tulemusi matemaatikas (50\%) ega ka eesti keele mõistmises (40\%). Keskpärase võimekusega kakskeelseid iseloomustas aga pigem potentsiaalikohane akadeemiline sooritus: $64 \%$ õpilastest sai matemaatikas ja 40\% eesti keeles keskpärase tulemuse. Lisaks ilmnes tüüpiline muster madala IQ tasemega kakskeelsete hulgas, kus eesti keele mõistmine jäi $71 \%$ juhtudest madalale tasemele.

Viies klassikeskkond koosnes klassidest, kus õppisid väga erinevate võimetega lapsed (heterogeensed klassid), aga võimete keskmine tase klassis oli keskmisest kõrgem (20\% klassikomplektidest). Sinna kuulus $21 \%$ õpilastest. Selles õpikeskkonnas eristus kolm mustrit. Esiteks, kõrge 
võimekuse tasemega kakskeelsed ei realiseerinud oma potentsiaali matemaatikas (44\%) ja eesti keeles (56\%). Samalaadne muster ilmnes ka eestikeelsete andekate õpilaste hulgas: 46\%l kõrge IQ tasemega eestikeelsetel õpilastel jäi matemaatikas ja 29\%l eesti keeles arengupotentsiaal realiseerimata. Kolmandaks, ilmnes tüüpiline muster, kus 54\% keskpärase IQ tasemega eestikeelsetest õpilastest näitas eesti keele mõistmises potentsiaalile vastavaid tulemusi.

Kokkuvõtvalt võib tulemuste põhjal väita, et koolimaastikul eristus koos õppivate laste võimekuse taseme ja selle varieeruvuse põhjal viis suuremat õpikeskkonda. Need toetasid laste arengut ja potentsiaali realiseerumist akadeemilistes tulemustes erinevalt. Osas klassikomplektides tulid esile õpilaste rühmad, kelle arengut saaks veelgi paremini toetada: kakskeelsete hulgas eelkõige keskpärase võimekusega lapsed ning osas õpikeskkondades nii eestikeelsed kui ka kakskeelsed andekad lapsed. Leidus ka õpikeskkondi, kus ilmnes selgelt positiivne mõju nii keskpäraste kui ka andekate õpilaste akadeemilisele arengule, seda just eestikeelsete õpilaste hulgas, ja kakskeelsete puhul vähem võimekate õpilaste seas.

\section{Õpetaja üldine toimetulek erinevates klassi õpikeskkondades}

Kuna uurimuse üks eesmärke oli analüüsida klassi õpikeskkonna mõju õpilaste, eraldi eesti- ja kakskeelsete potentsiaali realiseerumisele akadeemilistes tulemustes, siis peale klassikaaslaste faktori vaadeldi ka õpetaja panust õpikeskkonda. Klassikuuluvus kui õpikeskkond peegeldab ühelt poolt seal koos õppivate õpilaste omadusi - nende võimeid, õpimotivatsiooni, omavahelisi suhteid, vanematepoolset toetust -, kuid teiselt poolt ka õpetajaga seotud tegureid, sh oskust õpetada ja juhtida koos õppivaid õpilasi, arvestades nende eripäradega, kokkuvõtvalt õpetaja üldist toimetulekut klassi õpikeskkonnas (Creemers \& Kyriakides, 2008). Seega uurides iga klassi õpikeskkonda eraldi, saab teha kaudseid järeldusi selle kohta, kuidas tuleb õpetaja üldiselt toime klassis koos õppiva õpilasrühma eripäradega - nende erineva võimete taseme, õpimotivatsiooni ja muude teguritega, mis mõjutavad õppimisprotsessi klassis. Siinses uuringus osales 25 klassikomplekti, seega võib öelda, et sisuliselt oli tegemist 25 õpikeskkonnaga. Erineva vaimse potentsiaaliga klassikomplektide kontekstis pakkus huvi, milline seos on õpetaja üldisel toimetulekul õpilase akadeemilise edukusega matemaatikas ja eesti keele mõistmises, võttes arvesse õpilase enda vaimset potentsiaali, tema kodukeelt ja klassikaaslastega seotud õpikeskkonna panust. 
Koostatud regressioonimudel võimaldas ennustada õpilase 5. klassi akadeemilist edukust eraldi matemaatikas ja eesti keele mõistmises (sõltuvad muutujad), lähtudes õpilase IQ baastasemest (3. klassi tulemus), tema kodukeelest, viit tüüpi klassi õpikeskkonnast (olenevalt klassikaaslaste keskmisest vaimsete võimete tasemest ja selle varieeruvusest) ning õpetaja üldisest toimetulekust klassikomplektis, kus ta õpetas (sõltumatud muutujad). Esmalt koostati andmebaas, kus kolm viimast sõltumatut muutujat tuli ümber kodeerida $0 / 1$ süsteemi. Lapse kodukeele tunnus kodeeriti järgmiselt: väärtus 1 tähistas eestikeelset last ja väärtus 0 kakskeelset. Viit tüüpi klassi õpikeskkonna kohta tehti neli tulpa, kus igas tulbas tähistati väärtusega 1 üks õpikeskkond ning ülejäänud õpikeskkonnad märgiti väärtusega 0 . Lisaks tehti eraldi tulbad ka 21 õpikeskkonna kohta (need, kus ilmnes oluline seos õpilase akadeemilise arenguga, vt eelmine analüüs) - iga klassikomplekt tähistati väärtusega 1 . Niimoodi moodustus 21 õpikeskkonda, kus on kirjeldatud õpetaja üldist toimetulekut klassikomplektis. Seda alternatiivset kodeerimissüsteemi kasutades (nn dummy-coding) saadi üle regressioonanalüüsi piirangust, mis keelab kasutada mudelis kategoriaalse skaalaga tunnuseid, v.a juhul, kui need on dihhotoomse jaotuvusega. Regressioonanalüüside tulemused on toodud tabelis 7.

Tabelist on näha, et mõlemad regressioonimudelid osutusid statistiliselt oluliseks, kirjeldades edukust matemaatikas 20\%ga ja eesti keele mõistmises 31\%ga. Tulemused lubavad väita, et kui võtta arvesse õpikeskkonna näitajaid, on õpilase enda vaimne potentsiaal ning eesti keele mõistmises ka tema kodukeel siiski olulisel kohal. Samas on näha, et klassikaaslaste võimete taust õpikeskkonna puhul ei säilita oma tähtsust, kui võtta arvesse õpetajapoolset õpikeskkonna faktorit. Andmed võimaldasid matemaatika edukuse ennustajatena välja selgitada neli õpikeskkonda, kus õpetajad said klassikomplekti õpetamisel ja juhtimisel teiste õpetajatega võrreldes paremini või halvemini hakkama. Nimelt avaldas ühes õpikeskkonnas õpetaja üldine toimetulek klassikomplektiga õpilaste matemaatikatulemustele positiivset mõju ning kolmes keskkonnas oli näha, et nende õpetajate käe all saavad õpilased matemaatikas oluliselt nõrgemaid tulemusi. Eesti keele mõistmise puhul selgus viis klassi õpikeskkonda, millel oli pärssiv mõju õpilaste eesti keele mõistmisele. 
Tabel 7. Õpilase vaimse baasvõimekuse, kodukeele, 5 õpikeskkonna tüübi (kaasõpilaste vaimsete võimete taust ja selle varieerumine) ja 21 õpetajast tuleneva õpikeskkonna seos matemaatika edukusega ning eesti keele mõistmisega 5. klassis (kaks regressioonimudelit)

\begin{tabular}{l|c|c}
\hline \multirow{2}{*}{ Sõltumatu muutuja } & \multicolumn{2}{|c}{ Sõltuv muutuja } \\
\cline { 2 - 3 } & Matemaatika, 5. kl & Eesti keel - mõistmine, 5. kl \\
\hline Baas-IQ, 3. kI & $\boldsymbol{3}$ & $\boldsymbol{2}$ \\
\hline Kodukeel & $0,31^{* * *}$ & $0,23^{* *}$ \\
\hline Õpikeskkond_14 & 0,06 & $0,17^{* * *}$ \\
\hline Õpikeskkond_5 & $0,11^{*}$ & \\
\hline Õpikeskkond_13 & $-0,13^{*}$ & $-0,13^{*}$ \\
\hline Õpikeskkond_20 & $-0,11^{*}$ & $-0,15^{* *}$ \\
\hline Õpikeskkond_21 & $-0,14^{* *}$ & $-0,16^{* *}$ \\
\hline Õpikeskkond_6 & & $-0,22^{* *}$ \\
\hline Õpikeskkond_7 & $19,72^{*} \%$ & $-0,22^{* * *}$ \\
\hline Õpikeskkond_8 & 316 & 312 \\
\hline$N$ & $7,49^{* * *}$ & $13,49^{* * *}$ \\
\hline$F$ & $10 ; 305$ & $10 ; 301$ \\
\hline Vabadusastmed & 0,44 & 0,56 \\
\hline$R$ & & $30,95 \%$ \\
\hline Seletusmäär & & \\
\hline & & \\
\hline
\end{tabular}

Märkus. ${ }^{*}-p<0,05 ;{ }^{* *}-p<0,01 ;{ }^{* * *}-p<0,0001$.

Analüüsi tulemusena ilmnesid klassi õpikeskkonnad, kus õpetajad tulevad oma klassikomplekti õpetamisel teiste õpetajatega võrreldes üldiselt paremini või kehvemini toime, kuid selle põhjal ei ole võimalik öelda, millisel teguril on õpetaja puhul suurem osatähtsus. Edasi tuleks õpetajaid ja klassikomplekte kvalitatiivselt analüüsida. Esialgne uurimine näitab, et näiteks eesti keele puhul on viiest oluliselt nõrgemaks keskkonnaks osutunud kolm klassi, kus õpivad koos ainult kakskeelsed lapsed, kusjuures kahes klassikomplektis rakendatakse keelekümbluse metoodikat ja ühes neist toimub õpe eesti keeles ilma toetava programmita. Matemaatika puhul nende õpikeskkondade kohta esialgsel uurimisel midagi sarnast ei 
leitud. Selgus üks klassi õpikeskkond, kus võis täheldada õpetaja üldise toimetuleku kui õpikeskkonna pärssivat mõju õpilaste akadeemilisele tulemusele mõlemas valdkonnas nii matemaatikas kui ka eesti keele mõistmises. See klassikomplekt kuulus klasside hulka, kus ópivad koos väga erinevate võimetega lapsed (heterogeenne klass), aga võimete keskmine tase klassis oli keskmisest kõrgem. Samas õppis selles klassis väike hulk kakskeelseid. Seega võiks edaspidine põhjalikum kvalitatiivne analüüs anda vastuse küsimusele, mis faktor või faktorid (kas õpetajapoolsed, vanematest või klassikaaslastest tingitud või erinevate tegurite kombinatsioonid) võiks täpsemalt mõjutada õpilaste vaimse potentsiaali realiseerumist nende akadeemilistes tulemustes.

\section{Arutelu}

Uurimuse eesmärk oli analüüsida, kuidas arenevad eesti koolis koos õppivad eesti- ja kakskeelsed lapsed. Meie pikiuurimuse tulemused kinnitasid varasemate uurimuste tulemusi, et 3. klassis olid eestikeelsete õpilaste matemaatikateadmised oluliselt paremad kui kakskeelsete rühmal (Kempert et al., 2011; Kikas, 2012; Tago \& Ots, 2010). Samas selgus, et aineõppele ülemineku alguseks (5. klass) olid kakskeelsed õpilased matemaatikas jõudnud sarnasele tasemele kui samas õpikeskkonnas õppivad eestikeelsed lapsed. Nii nagu varasemates uurimustes, selgus ka siin, et eesti keele mõistmises püsis kakskeelsete rühm kõigil kolmel aastal (3.5. klass) oluliselt kehvemal tasemel võrreldes eestikeelsetega (Uibu \& Tropp, 2012). Kui aga võtta arvesse ka õpilase vaimse võimekuse baastaset, selgus just indiviiditasandi analüüsi tulemusena (CFA), et akadeemilise edukuse madalam tase ei iseloomustanud ühtmoodi kõiki muukeelseid õpilasi. Võimekusele mittevastav madalam akadeemiline tase oli omane eelkõige keskpärase võimekusega kakskeelsetele lastele nii matemaatikas kui ka eesti keele mõistmises. Need õpilased on kakskeelsete hulgas riskirühm, kes tuleks õpetajatel ära tunda, et nende arengut paremini toetada. Võimalik, et suur hulk vähem võimekaid kakskeelseid ei areneks ka lisaabi korral kiiremini ning andekad kakskeelsed saaksid valdavalt ka ilma lisatoetuseta hakkama.

Uurimuse teine eesmärk oli analüüsida, kuidas arenevad erinevate vaimsete võimetega eesti- ja kakskeelsed õpilased klassi õpikeskkondades. Täpsemalt sooviti teada, kas selgunud arengumustrid lapse IQ ja akadeemiliste tulemuste vahel tulevad esile kindlates klassikeskkondades. Konfiguratsioonilise analüüsi tulemused kinnitasid, et klassikaaslaste 
vaimsete võimete mõju õpilase arengule on keerulisem, kui varasematest uuringutest on selgunud (Seepter, 2010): osas keskkondades leiavad kinnitust varasematest uuringutest leitud seosed, ent avalduvad ka uudsed või vastanduvad seosed.

Erinevalt varasematest töödest selgus, et vähem võimekate õpilaste puhul ei avalda heterogeenne keskkond rühma arengule ühest toetavat mõju (Lou et al., 1996; Seepter, 2012). Samas sai kinnitust eestikeelsete valimil põhinev varasem tulemus (Seepter, 2010), et väiksema keskmise võimekusega, kuid homogeensel õpikeskkonnal on positiivne mõju madalama IQ tasemega õpilase akadeemilisele sooritusele - seda just kakskeelsete hulgas. Samas klassikomplektis õppivate eestikeelsete laste puhul sellist mõju ei täheldatud.

Kui keskmiselt väiksema võimekusega ja ühtlase tasemega klassides avaldas keskkond madala IQ tasemega kakskeelsetele positiivset mõju, siis keskpärase võimekusega kakskeelsed said selles keskkonnas võimetele mittevastavaid tulemusi nii matemaatikas kui ka eesti keele mõistmises. See tulemus toetab Lou ja tema kolleegide (2000) mõtet, et ühtlaselt madala võimete tasemega rühmas võivad õpitulemused olla kehvad just sel põhjusel, et õpetaja ei anna õpilastele ülesandeid, mis sunniks neid oma võimeid proovile panema. Veelgi enam, meie analüüsist selgus, et kui klassikeskkond oli homogeenne, aga keskpärase keskmise võimekusega, siis avaldas see keskmise IQga eestikeelsetele õpilastele positiivset mõju, ent ka võimekate õpilaste akadeemilised tulemused vastasid nende võimetele. Selline uurimistulemus on kooskõlas varasemaga (Lou et al., 1996), mille kohaselt võimete poolest homogeenses rühmas on õpetajal kõigile õpilastele lihtsam juhiseid anda, lähtudes nende võimetest ja teadmiste tasemest.

Võimekamate õpilaste puhul võis tulemuste põhjal täheldada üldist tendentsi, et kui võimete keskkond klassis muutus heterogeensemaks, siis ilmnes üha märkimisväärsem hulk kõrge IQ tasemega eesti- ja kakskeelseid lapsi, kelle akadeemilised tulemused ei vastanud nende võimetele. See tendents on kooskõlas ka varasemate tulemustega (Seepter, 2010). Näiteks avaldas mõõdukalt varieeruvate, kuid keskmisest kõrgema võimete tasemega keskkond, mis mõjutas keskpärase IQga eestikeelsete õpilaste akadeemilist edukust positiivselt, kõrge IQ tasemega eestikeelsete matemaatikatulemustele kahesugust mõju. Kui valdav osa neist sai matemaatikas võimetekohaseid tulemusi, siis leidus ka märkimisväärne hulk (26\%) õpilasi, kelle vaimne potentsiaal matemaatikas ei realiseerunud. Veelgi enam, sarnastes keskmisest suurema võimekusega klassides, kus võimete tase oli heterogeenne, ilmnes võimekamate eesti- ja kakskeelsete õpilaste puhul, et nende potentsiaal matemaatikas ei realiseerunud. 
Ilmselt viitavad vastukäivad seosed klassikaaslaste kui õpikeskkonna mõjust õpilase arengule, et peale klassikaaslaste vaimse tausta on veel midagi, mis soodustab või pärsib selle mõju õpilase akadeemilisele arengule. See võib olla õpetaja üldine toimetulek ja tema õpetamispraktika sobivus klassikomplektiga (Gamoran, 1986; Jordan, Lindsay, \& Stanovich, 1997) või koduse keskkonna ja vanemate mõju (Englund, Luckner, Whaley, \& Egeland, 2004; Seepter, 2010) või veel mingi kombinatsioon teistest teguritest (nt Tago \& Ots, 2010). Siinses uuringus kontrolliti õpetaja üldise toimetuleku mõju õpilase akadeemilisele edukusele, võttes arvesse ka klassikaaslaste võimete tausta. Kinnitust leidis hüpotees, et õpilase akadeemilise tulemuslikkuse olulisim ennustaja on just see, kuidas õpetaja tuleb erinevate võimete taustaga klassikomplektidega toime, mitte lihtsalt koos õppivate õpilaste vaimsed võimed (Gamoran, 1986; Lou et al., 2000). Analüüsi käigus tuvastati küll klassi õpikeskkonnad, kus õpetajad tulevad oma klassikomplekti õpetamisel teiste õpetajatega võrreldes üldiselt paremini või kehvemini toime, kuid analüüsitulemused ei võimalda öelda, mis tegur täpsemalt on õpetaja puhul tähtis. Seda peaks edaspidi juba kvalitatiivselt analüüsima, võttes vaatluse alla uuringus selgunud hea ja halva praktika näited.

Kokkuvõtvalt võib tulemuste põhjal väita, et koolimaastikul eristus koos õppivate laste võimekuse taseme ja selle varieeruvuse alusel viis suuremat õpikeskkonda. Need keskkonnad toetasid laste arengut ja potentsiaali realiseerumist akadeemilistes tulemustes erinevalt. Osas klassikomplektides tulid esile õpilaste rühmad, kelle arengut saaks veelgi paremini toetada: kakskeelsete hulgas eelkõige keskpärase võimekusega lapsed (keskmisest madalama IQ tasemega ja homogeensetes klassikomplektides) ning osas õpikeskkondades (heterogeensed klassikomplektid) nii eestikeelsed kui ka kakskeelsed andekad lapsed. Leidus õpikeskkondi, kus võis täheldada positiivset mõju nii keskpäraste kui ka andekate õpilaste akadeemilise arengule (just eestikeelsete õpilaste hulgas ja kakskeelsete puhul väiksema võimekusega õpilaste seas).

Uuringu tulemused osutavad vajadusele kasutada erinevates klassi õpikeskkondades erinevaid õpetamisviise ja/või õppekorraldust. Siinkohal saaks kool õpetajatele korraldusliku poole pealt abiks olla, näiteks õpetajate ja abispetsialistide koostöö veel paindlikumal korraldamisel (mitmete spetsialistide üheaegne kaasamine klassi óppetöösse, nt tehes rühmatöid ja võimaldades neile eri ruume). Ühtlasi on uurimistulemused abiks õpetajakoolituse spetsialistide ettevalmistamisel, sest need osutavad vajadusele anda ópetajatele täpsemaid teadmisi, juhiseid ja oskusi, mis võimaldaksid neil toime tulla väga erinevate klassi õpikeskkondade juhtimise ja õpetamisega. 


\section{Tänusõnad}

Uuringut ja artikli kirjutamist on toetanud Eesti Haridus- ja Teadusministeerium (grant 10.1-8.1/1794), ESFi programm Eduko (grant 30.2-1/549).

\section{Kasutatud kirjandus}

Bergman, L. R., \& El-Khouri, B. M. (2002). SLEIPNER: A statistical package for pattern-oriented analysis. Version 2.1. Stockholm: Stockholm University.

Bialystok, E. (1988). Levels of bilingualism and levels of linguistic awareness. Developmental Psychology, 24(4), 560-567. http://dx.doi.org/10.1037/0012-1649.24.4.560

Bialystok, E. (2009). Bilingualism: The good, the bad, and the indifferent. Bilingualism: Language an Cognition, 12(1), 3-11.

http://dx.doi.org/10.1017/S1366728908003477

Bialystok, E., \& Majumder, S. (1998). The relationship between bilingualism and the development of cognitive processes in problem-solving. Applied Psycholinguistics, 19(1), 69-85. http://dx.doi.org/10.1017/S0142716400010584

Bialystok, E., \& Viswanathan, M. (2009). Components of executive control with advantages for bilingual children in two cultures. Cognition, 112(3), 494-500. http://dx.doi.org/10.1016/j.cognition.2009.06.014

Bloom, B. S. (1971). Mastery learning. In J. H. Block (Ed.), Mastery learning: Theory and practice (pp. 47-63). New York: Holt, Rinehart \& Winston.

Carreker, S. H., Neuhaus, G. F., Swank, P. R., Johnson, P., Monfils, M. J., \& Montemayor, M. L. (2007). Teachers with linguistically informed knowledge of reading subskills are associated with a Matthew effect in reading comprehension for monolingual and bilingual students. Reading Psychology, 28(2), 187-212. http://dx.doi.org/10.1080/02702710601186456

Cheng, R. W., Lam, S., \& Chan, J. C. (2008). When high achievers and low achievers work in the same group: The roles of group heterogeneity and processes in project-based learning. British Journal of Educational Psychology, 78(2), 205-221. http://dx.doi.org/10.1348/000709907X218160

Creemers, B. P. M., \& Kyriakides, L. (2008). The dynamics of educational effectiveness: A contribution to policy, practice and theory in contemporary schools. London: Routledge, Taylor \& Francis Group.

Englund, M. M., Luckner, A. E., Whaley, G. J. L., \& Egeland, B. (2004). Children's achievement early elementary school: Longitudinal effects of parental involvement, expectations and quality of assistance. Journal of Educational Psychology, 96(4), 723-730. http://dx.doi.org/10.1037/0022-0663.96.4.723

Gamoran, A. (1986). Instructional and institutional effects of ability grouping. Sociology of Education, 59(4), 185-198. http://dx.doi.org/10.2307/2112346

Gonzales, P., Williams, T., Jocelyn, L., Roey, S., Kastberg, D., \& Brenwald, S. (2008). Highlights from TIMSS 2007: Mathematics and science achievement of U.S. fourth- and eighth-grade students in an international context. (ERIC Document Reproduction Service No.: ED 503-625). 
Hooper, S., \& Hannafin, M. J. (1988). Cooperative CBI: The effects of heterogeneous versus homogeneous grouping on the learning progressively complex concepts. Journal of Educational Computing Research, 4(4), 413-424. http://dx.doi.org/10.2190/T26C-3FTH-RNYP-TV30

Indurkhya, A., \& von Eye, A. (2000). The power of tests in configural frequency analysis. Psychologische Beitrage, 42(3), 301-308.

Jordan, A., Lindsay, L., \& Stanovich, P. J. (1997). Classroom teachers' instructional interactions with students who are exceptional, at risk, and typically achieving. Remedial and Special Educations, 18(2), 82-93.

http://dx.doi.org/10.1177/074193259701800202

Kempert, S., Saalbach, H., \& Hardy, I. (2011). Cognitive benefits and costs of bilingualism in elementary school students: The case of mathematical word problems. Journal of Educational Psychology, 103(3), 547-561. http://dx.doi.org/10.1037/a0023619

Kikas, E. (2012). Cognitive abilities and math achievement of students from Estonian-, Estonian-Russian, and Russian-speaking families in Estonian-language classrooms. In A. Toomela \& E. Kikas (Eds.), Children studying in a wrong language: Russian speaking children in Estonian school twenty years after the collapse of the Soviet Union (pp. 43-79). Frankfurt am Main: Peter Lang.

Kuusinen, J., \& Leskinen, E. (1988). Latent structure analysis of longitudinal data on relations between intellectual abilities and school achievement. Multivariate Behavioral Research, 23(1), 103-118. http://dx.doi.org/10.1207/s15327906mbr2301_6

Lou, Y., Abrami, P. C., \& Spence, J. C. (2000). Effects of within-class grouping on student achievement: An exploratory model. Journal of Educational Research, 94(2), 101-112. http://dx.doi.org/10.1080/00220670009598748

Lou, Y., Abrami, P. C., Spence, J. C., Poulsen, C., Chambers, B., \& d'Apolonia, S. (1996). Within-class grouping: A meta-analysis. Review of Educational Research, 66(4), 423-458. http://dx.doi.org/10.3102/00346543066004423

Lynn, R., Pullmann, H., \& Allik, J. (2003). A new estimate of the IQ in Estonia. Perceptual and Motor Skills, 97(2), 662-664.

http://dx.doi.org/10.2466/pms.2003.97.2.662

Raven, J. (1981). Manual for Raven's progressive matrices and Mill Hill vocabulary scales. Oxford: Oxford Psychologists Press.

Rohde, T. E., \& Thompson, L. A. (2007). Predicting academic achievement with cognitive ability. Intelligence, 35(1), 83-92. http://dx.doi.org/10.1016/j.intell.2006.05.004

Seepter, K. (2010). Longitudinal study of cognitive influences of peers, teacher's knowledge and parental expectations on pupils' achievement: Impact on low-, average- and high-ability pupils. In A. Toomela (Eds.), Systemic person-oriented study of child development in early primary school (pp. 25-46). Frankfurt am Main: Peter Lang.

Seepter, K. (2012). Relations between mono- and bilingual pupils' math achievement and teachers' knowledge of special education needs. In A. Toomela \& E. Kikas (Eds.), Children studying in a wrong language: Russian-speaking children in 
Estonian school twenty years after the collapse of the Soviet Union (pp. 153-162). Frankfurt am Main: Peter Lang.

Slavin, R. E. (1987). Ability grouping and student achievement in elementary schools: A best evidence synthesis. Review of Educational Research, 57(3), 293-336. http://dx.doi.org/10.3102/00346543057003293

Tago, M., \& Ots, A. (2010). Pupils who speak a „wrong” language: Bilingual children's academic achievement in submersion education. In A. Toomela (Ed.), Systemic person-oriented study of child development in early primary school (pp. 133-154). Frankfurt am Main: Peter Lang.

Toomela, A., Kikas, E., \& Mõttus, E. (2006). Ability grouping in schools: A study of academic achievement in five schools in Estonia. Trames, 10(1), 32-43.

Uibu, K., \& Tropp, K. (2012). Bilingual and monolingual students' linguistic competences and their development at Estonian primary school. In A. Toomela \& E. Kikas (Eds.), Children studying in a wrong language: Russian speaking children in Estonian school twenty years after the collapse of the Soviet Union (pp. 17-41). Frankfurt am Main: Peter Lang.

Vabariigi Valitsus (2007). Põhikooli ja gümnaasiumi riiklik õppekava. Riigi Teataja I 2007, 40, 294. Külastatud aadressil https://www.riigiteataja.ee/ert/act.jsp?id=802290.

Von Eye, A. (1990). Introduction to configurational frequency analysis: The search for types and antitypes in cross-classifications. Cambridge: Cambridge University Press.

Vuorenkoski, L., Kuure, O., Moilanen, I., Penninkilampi, V., \& Myhrman, A. (2000). Bilingualism, school achievement, and mental wellbeing: A follow-up study of return migrant children. Journal of Child Psychology and Psychiatry, 41(2), 261266. http://dx.doi.org/10.1111/1469-7610.00607

Özerk, K. (2001). Teacher-student verbal interaction and questioning, class size and bilingual students' academic performance. Scandinavian Journal of Educational Research, 45(4), 353-367. http://dx.doi.org/10.1080/00313830120096761 


\title{
Bilingual and Estonian-speaking children studying in the same classes: relation of academic achievement to the pupil's mental ability and classroom learning environment
}

\author{
Kristina Seepter ${ }^{\mathrm{al}}$ \\ a Tallinn University, Institute of Psychology
}

\begin{abstract}
Summary
The objective of this study was to analyse the development of Estonianspeaking and bilingual children in Estonian schools. The author studied whether the children realise their baseline mental ability and develop accordingly in mathematics and Estonian. Additionally, it was described, which learning environments support or degrade pupils' development and realisation of their mental potential.

Samples of 25 classrooms of mixed Estonian and bilingual children were included in the study. Pupils' general mental ability was measured in the third grade. This data was matched with attained levels of mathematics and understanding of Estonian in the fifth grade. The classroom's learning environment was described through the average IQ and its variability as well as teacher's general efficacy of teaching skills and practices applied. To interpret the collected information, both group (regression and dispersion analysis) and individual level (configural frequency analysis) statistical methods were used.

The results showed that by the time of leaving the classroom-based teaching system and moving to the subject teaching system (in the fifth grade), the level of mathematics achievement in bilingual children was similar to the achievement of Estonian-speaking pupils studying in the same learning environment. In understanding of the Estonian language, the bilingual children remained at a lower level throughout all three years of the study. It is important to note that the achievement gap was not universal to all bilingual children but was prevalent in particular with bilingual pupils with average mental abilities. This group of bilingual
\end{abstract}

Institute of Psychology, Tallinn University, Narva Road 29, 10120 Tallinn, Estonia; kristina.seepter@ut.ee 
pupils is under threat of degraded development and should be more thoroughly monitored by their teachers.

The second objective of this study was to find out how bilingual and Estonian-speaking pupils with different mental potential develop in certain learning environments. It was investigated whether previously noted patterns of children's IQ and academic achievement will surface only in certain classroom environments.

It was found that bilingual pupils with average mental abilities have development problems in homogeneous classrooms with children of below average IQ. Additionally, there was an alarming tendency that both bilingual and Estonian-speaking pupils with above average mental potential did not realise their potential in mentally heterogeneous classrooms. In classrooms of moderately variable but above average mental abilities, and homogeneous classrooms with average mental abilities, positive effects on academic achievement appeared both in pupils with average and above average mental potential, especially concerning Estonian-speaking pupils. With bilingual pupils, the positive effect of the learning environment appeared in pupils with a lower mental potential who studied in classrooms with a homogeneously low mental average potential.

The results of this study reveal that differences in development in various learning environments may be linked to the arsenal of teacher's knowledge and practices applied to a certain classroom. For example, in heterogeneous classrooms many teachers (and school systems) are not able to offer support to all mentally varied groups of children learning in the same classroom. Usually, children with average and above average mental potential are the ones who suffer and do not realise their potential.

The results of this study point to the need to apply different teaching practices or even school systems in different classrooms. This is an area where school can support teachers from the organisational side, by flexibly integrating assisting specialists into lessons, dividing classrooms into different groups and supporting group work, etc. On the other hand, it is important that the educational and coaching system for teachers includes an understanding of the need to give teachers exact and specific knowledge, skills and practices to support their work in the variety of classrooms they are likely to encounter.

Keywords: longitudinal exploratory study, bilingual children, pupils' general mental ability, average IQ of the class and variance, teachers' general efficacy, academic achievement 